\title{
Isolation and characterization of circadian clock genes in the biofuel plant Pongamia (Millettia pinnata)
}

\author{
Harry P Winarto ${ }^{1}$, Lim Chee Liew ${ }^{1}$, Peter M Gresshoff ${ }^{2}$, Paul Scott ${ }^{2}$, Mohan B Singh, and \\ Prem L Bhalla* \\ Plant Molecular Biology and Biotechnology Laboratory, ARC Centre of Excellence for Integrative Legume \\ Research, Melbourne School of Land and Environment, The University of Melbourne, Parkville, Victoria \\ 3010, Australia.
}

\author{
* Corresponding author \\ Professor Prem L Bhalla \\ Melbourne School of Land and Environment, \\ The University of Melbourne, \\ Parkville, Victoria 3010, \\ Australia \\ Phone/Fax: +61 383449651 \\ Email: premlb@unimelb.edu.au
}

\author{
${ }^{1}$ These authors contributed equally to the article \\ ${ }^{2}$ ARC Centre of Excellence for Integrative Legume Research, The University of Queensland, St. Lucia, \\ Brisbane, Queensland 4072, Australia
}

\begin{abstract}
The increasing human population has led to an inevitable increase in global energy demands. In the recent decades, biofuels have emerged as one of the potential solutions to the world's insatiable energy needs while reducing the high reliance on fossil fuels. Pongamia (Millettia pinnata), a nitrogen-fixing tree legume, has shown a great promise as an oil source for the production of biofuel with economical and environmental benefits. The generation of Pongamia-derived biofuel is dependent on the success of flowering and seed development. However, molecular control of floral initiation pathways in Pongamia remains largely unexplored. Photoperiod pathway has been reported to be one of the major checkpoints of plant flowering time and flower initiation. The circadian clock pathway, a part of the photoperiod pathways, is one of the key regulators of flowering time. Here, we report the identification of four Pongamia circadian clock genes (ELF4, LCL1, PRR7, and TOC1) through the mapping of the Pongamia transcriptome short-paired reads library, by using soybean circadian clock genes as the reference sequences. Furthermore, multiple alignments and phylogenetic analyses suggested that Pongamia clock genes are conserved among legume crops such as soybean, medicago, and garden pea. Gene expression studies highlight that Pongamia circadian clock genes are diurnally regulated under long- day conditions. Thus, this study reports the isolation and characterization of circadian clock genes in Pongamia and enhances our understanding of the molecular mechanism of flowering control in Pongamia.
\end{abstract}

Keywords: circadian clock; pongamia; soybean; biofuel; flowering 


\section{Introduction}

A substantial increase in the human population has led to an inevitable increase in energy requirements. For example, global energy consumption rose by $2.5 \%$ in 2011 and $1.8 \%$ in 2012 [1]. As fossil fuels account for $87 \%$ of the world's energy consumption, the increased utilization resulted in the production of more harmful greenhouse gases, such as carbon dioxide $\left(\mathrm{CO}_{2)}\right.$ and nitrous oxide $\left(\mathrm{N}_{2} \mathrm{O}\right)$, which led to the observable global climate change [2]. Although the demand for crude oil rose by only $0.9 \%$ in 2012 , crude oil is still the world's primary fossil fuel, accounting for $33.1 \%$ of global energy use [1]. Due to the increasing energy demand every year, oil reserves that took millions of years to form are being depleted much more rapidly, leading to the concern that the currently available sources of fossil fuels will be exhausted in the near future [3]. Accordingly, there is a pressing need to find alternative energy sources to fulfill the world's insatiable energy demand [4]. For the past decades, biofuels have emerged as one of the potential solutions to the world's growing energy needs.

Ideally, the sources of such biofuels will have minimal impact on the environment, global food supplies, and land and water use; tree legumes have been considered strong candidates as biofuel sources that meet the aforementioned criteria [5,6]. Considering the many economical and environmental benefits of tree legumes, as explained by Biswas et al. $(2011$; 2013) and Jensen et al. (2012) [5,6], Pongamia (Millettia pinnata, previously known as Pongamia pinnata) serves as an excellent feedstock (raw material) for the production of biodiesel [7]. Pongamia is a fast-growing, medium-sized legume tree that is drought and salt-tolerant. Pongamia is also perennial and has symbiotic relationships with rhizobia bacteria and mycorrhizal fungi $[8,9,7,10]$. Scott et al. (2008) described several characteristics of Pongamia's seed oil that are considered desirable traits in the production of biodiesel. For instance, the oil consists of predominantly ( $50 \%)$ mono-unsaturated oleic acid and has low amounts of saturated palmitic and stearic acids. Ideally, these characteristics are important in the generation of low cloud-point (the temperature at which dissolved solids will separate from the oil) and low pour-point (the lowest temperature at which oil will flow) fuel to be used in temperate and cold climates.

Recently, Jatropha spp., another oilseed candidate for biodiesel production, has caused detrimental investment loss due to unexpected lower seed production [11]. Hence, there is an obvious need to strengthen the industrial development of Pongamia as a sustainable biofuel source $[12,7]$. As seed production is reliant upon flowering and fertilization, understanding the flowering 
mechanisms that control the production of these seeds is important. Photoperiod pathway has been reported as a major control of plant flowering time [13-19]. Although the physiological properties of flowering in Pongamia have captured the attention of many researchers [20, 12, 21, 22], the role of the photoperiodic response of Pongamia in the regulation of flowering time remains largely unknown. In particularly, the circadian clock, a part of the photoperiod pathway function as a system to synchronise photoperiod and other environmental cues with the internal rhythm [23]. In Arabidopsis, input pathways, such as light and temperature, are responsible for the entrainment of the central oscillator, which consists of a complex network of interconnected morning and evening transcriptional loops. Some of the morning genes include CIRCADIAN CLOCK ASSOCIATED 1 (CCA1); LATE ELONGATED HYPOCOTYL (LHY); and PSEUDO-RESPONSE REGULATOR 5, 7, and 9 (PRR5, PRR7, and PRR9); while the evening genes consist of EARLY FLOWERING 3 and 4 (ELF3 and ELF4); GIGANTEA (GI); LUX ARRHYTHMO (LUX); and TIMING OF CAB EXPRESSION 1 (TOC1). Besides transcriptional regulation, the interactions between these components are also regulated through post-transcriptional, post-translational, and chromatinremodeling mechanisms that modulate the rhythmic properties of the oscillator [24-26].

There are significant challenges in translating knowledge gained from the model plant, Arabidopsis to other plant species because different plants such as legumes not only display unique vegetative and floral developmental complexities but also have different requirement for the floral transition to happen. By anticipating cyclic changes of circadian rhythms mentioned above, the organism has the adaptive advantage of being able to coordinate essential developmental and physiological processes to occur at optimal times of the day, thus enhancing adaptation, fitness, and survival [27-29]. In order to trigger flower initiation at the precise time and in the right conditions, circadian clocks perceive and integrate both environmental and endogenous signals, which in turn activate mobile floral stimulus ("florigen", FLOWERING LUCUS T (FT)) genes to induce flowering. Circadian clock genes have been reported to be responsible for natural variation across different climate and geography locations [30-32,19]. Therefore, there is a need to understand the fundamental pathways that regulate the response to the environment and flowering control to improve breeding for suitable cultivars adapted to climate changes and biofuel production.

In this study, we have used soybean as a reference plant: unlike that of Pongamia, the soybean genome has been fully sequenced, and many soybean orthologs of the Arabidopsis circadian clock genes have been reported [33,34]. In addition, recently soybean has been focus of flowering studies [34-43] and belongs to the phaseoloid subfamily, is closely related to the Pongamia millettioid subfamily in the evolutionary tree [44]. Since the Pongamia genome sequence 
is unavailable, we utilized bioinformatics approaches to initially identify the Pongamia homologs of soybean circadian clock genes. This was conducted through the mapping of the Pongamia transcriptome short-paired reads library (SRA046342.1) [45]. The putative Pongamia circadian clock genes were then isolated to determine-through protein alignment and phylogenetic analyses - the extent of conservation with other species. We also investigated the expression rhythm of putative circadian clock genes in juvenile Pongamia plants under favorable long-day conditions for flowering.

\section{Materials and Methods}

\section{Plant Material and Growth Conditions}

Pongamia seeds, obtained from Brisbane, Queensland, were imbibed in distilled water (1 L per 100 seeds) for $48 \mathrm{~h}$ at $25^{\circ} \mathrm{C}$. Seeds were then germinated and grown under long-day conditions (18 $\mathrm{h}$ light, $6 \mathrm{~h}$ dark) at $28{ }^{\circ} \mathrm{C}, 400 \mathrm{UML}\left(\mu \mathrm{mol} \cdot \mathrm{m}^{-2} \cdot \mathrm{s}^{-1}\right)$ and $70 \%$ humidity in Percival I-36VL growth incubators (Percival, USA).

\section{Bioinformatics}

The sequences of soybean circadian clock genes [33], sourced from the Phytozome v8.0 database (available at http://www.phytozome.net/) [46], were used to identify the homologs in Pongamia. Geneious Pro v6 software [47] was then used to map Pongamia's transcriptome (SRA046342.1) short-paired reads library to the soybean reference gene sequences. Iterative fine tuning from the program was then used to improve the mapping result by obtaining more short-paired reads extending into regions where reads were previously un-mappable (Supplementary Figure S1). This fine-tuning allowed the design of primer pairs for full-length gene isolation in Pongamia according to the soybean reference sequences. Primers were designed using Primer3 (available at http://frodo.wi.mit.edu/primer3) found in Geneious Pro v6 on the Pongamia short-paired reads mapping results (Supplementary Table S1).

\section{Gene isolation}

Total RNA was extracted from trifoliate leaves using TRIzol® reagent (Invitrogen Life Technologies, USA) according to the manufacturer's instructions. The RNA samples were then treated with DNase I (Ambion, Applied Biosystem, USA) to remove genomic DNA contamination as per the manufacturer's instructions, followed by phenol-chloroform extraction to inactivate the 
DNase I. First-strand complementary DNA (cDNA) was synthesized from $1 \mu \mathrm{g}$ of total RNA using SuperScript $^{\mathrm{TM}}$ III Reverse Transcriptase (Invitrogen Life Technologies, USA) according to the manufacturer's instructions. Reverse transcriptase polymerase chain reactions (RT-PCRs) were performed using Taq DNA polymerase (Invitrogen Life Technologies, USA) according to manufacturer's instructions using a Mastercycler ${ }^{\circledR}$ Nexus thermal cycler (Eppendorf, Germany). The PCR products were cloned into a pGEM $^{\circledR}-\mathrm{T}$ Easy Vector System and sequences were confirmed by sequencing (Australian Genome Research Facility, Australia).

\section{Alignment and Phylogenetic Analysis}

Amino acid sequences of circadian clock proteins of plant species were obtained by subjecting the Arabidopsis circadian clock proteins to tBLASTn searches on the National Center for Biotechnology Information (NCBI) database (http://www.ncbi.nlm.nih.gov). Protein alignments were performed using Geneious settings (cost matrix, 65\% similarity; gap open penalty, 12; and gap extension penalty, 3). The neighbor-joining method was used to build the phylogenetic tree with 1000 replicates [43]. Protein domains were then identified using the PROSITE database from ExPASy (available at http://prosite.expasy.org/).

\section{DNA extraction and Southern Blot}

Pongamia genomic DNA was extracted according to a modified CTAB method [48] with modification. In brief, $1 \mathrm{~g}$ of the ground Pongamia leaf tissues in $10 \mathrm{~mL}$ of $2 \mathrm{x}$ CTAB extraction buffer (2\% CTAB w/v, 75 mM Tris pH 8.0, 15 mM EDTA pH 8.0, $1.05 \mathrm{M} \mathrm{NaCl}, 1 \%$ PVP, 0.6\% $\beta$-mercaptoethanol) was incubated at $65^{\circ} \mathrm{C}$ for 1 hour. An equal volume of chloroform/isoamyl alcohol (24:1) was added and gently shaken for 10 minutes at room temperature. The mixture was centrifuged at 4,500 rpm for 15 minutes, and the aqueous phase was transferred to a new tube, before subjected for RNase A $(20 \mathrm{mg} / \mathrm{mL})$ treatment at $37^{\circ} \mathrm{C}$ for $30 \mathrm{~min} .1 / 10$ volume of $10 \%$ $\mathrm{CTAB}(10 \% \mathrm{CTAB}, \quad 0.7 \mathrm{M} \mathrm{NaCl})$ warmed at $55^{\circ} \mathrm{C}$ was added. Equal volume of chloroform:isoamyl alcohol (24:1) was added again and mixed gently. The mixture was centrifuged at 4,500rpm for 15 minutes. The aqueous phase was transferred to a new tube and genomic DNA was precipitated with $2 / 3$ volume of ice - cold isopropanol by incubating on ice for $30 \mathrm{~min}$. The mixture was then centrifuged at $4500 \mathrm{rpm}$ at $15{ }^{\circ} \mathrm{C}$ for $10 \mathrm{~min}$. The pellet was washed with cold 75 $\%$ ethanol, before centrifugation for 5 minutes at 10,000 rpm. The pellet containing nucleic acids obtained was dried and redissolved in $100 \mu \mathrm{L}-300 \mu \mathrm{L}$ TE (10 mM Tris-Cl, pH 7.5, 1 mM EDTA). 
Southern blot was carried out according to modified protocols of Southern et. al. 2006 [49]. $15 \mu \mathrm{g}$ of the extracted genomic DNA was digested overnight with EcoRI, BamHI and/or HindIII restriction enzymes. The digested DNA together with digoxigenin (DIG)-labeled DNA molecular weight marker (Roche Diagnostics Corporation, USA) were separated in $0.8 \%$ agarose gel, blotted to nitrocellulose membrane and hybridized with DIG-labeled probe of ELF4, LCL1, PRR7 or TOC1 gene. The probe DNA fragments were synthesized by PCR using DIG-dUTP, according to the manufacturer's instructions (Roche Diagnostics Corporation, USA). Hybridization was performed at $55{ }^{\circ} \mathrm{C}$ for 16 hours. Chemiluminescent detection of hybridization signals was observed using CDP-star according to the manufacturer's instructions (Roche Applied Science, Germany).

\section{Tissue Sampling and Gene Expression}

Gene expression studies were conducted under long-day conditions (18 h light, $6 \mathrm{~h}$ dark) in Percival I-36VL growth incubators (Percival, USA). The seedlings were entrained for five weeks before harvesting. Samples at seven time points after light treatment were collected in $4 \mathrm{~h}$ intervals across a $24 \mathrm{~h}$ period. Three biological replicates were obtained, and each replicate consists of two trifoliate leaves randomly pooled together from two different plants. Total RNAs were then extracted using $\mathrm{TRIzol}^{\circledR}$ reagent. Reverse transcription was conducted using $1 \mu \mathrm{g}$ of total RNA using SuperScript ${ }^{\mathrm{TM}}$ III Reverse Transcriptase according to manufacturer's instructions. A negative control in the absence of reverse transcriptase (RT-negative) was included for each sample to ensure lack of genomic DNA contamination.

To examine the quantitative expression profile of ELF4, LCL1, PRR7, and TOC1 genes, quantitative real time RT-PCR (qRT-PCR) was performed with $1.5 \mu \mathrm{L}$ cDNA template in a $10 \mu \mathrm{L}$ reaction volume using Brilliant III Ultra-Fast SYBR ${ }^{\circledR}$ Green QPCR Master Mix (Agilent, USA) with the Stratagene Mx3000PтM System (Agilent, USA). The thermal profile of the reactions included an initial denaturation step at $95{ }^{\circ} \mathrm{C}$ for $3 \mathrm{~min}$, followed by 40 cycles of: $95{ }^{\circ} \mathrm{C}$ for $30 \mathrm{~s}$, the appropriate annealing temperature of qRT-PCR primers (Supplementary Table S1) for $30 \mathrm{~s}$, and 72 ${ }^{\circ} \mathrm{C}$ for $30 \mathrm{~s}$. The reaction was finalized by a dissociation cycle of $95{ }^{\circ} \mathrm{C}$ for $1 \mathrm{~min}$, followed by a stepwise increase from $55{ }^{\circ} \mathrm{C}$ to $95{ }^{\circ} \mathrm{C}$ (with a $1{ }^{\circ} \mathrm{C}$ increase every $30 \mathrm{~s}$ ) to obtain the melting curves of the end products. Two technical replicates were performed for each sample. Standards, a notemplate control, and an RT-negative sample were included in each run.

The log scale of the cycle threshold (CT) plots with adjusted threshold values between the technical replicates was used for the qRT-PCR analysis. The expression level of each gene was 
normalized against the expression of CONS7, a Pongamia housekeeping gene [50,51]. The relative transcript levels for each gene were then measured using amplification efficiency (E; assumed to be 2) and deviation of threshold cycle between the reference and target gene ( $\Delta \mathrm{CT})$ according to the following equation:

$$
\text { Relative transcript level of target gene }=\left(E_{\text {target }}\right)^{\Delta C T(\text { reference-target })}
$$

The average (mean \pm standard error) from all three biological replicates was then used to plot the expression level of each gene at different time points.

\section{Results}

\section{Identification and Isolation of Putative Circadian Clock Genes in Pongamia}

By mapping the Pongamia transcriptome short paired reads library to the coding sequences of soybean clock gene homologues, the Pongamia counterparts were identified. Subsequently, the mapping result was improved by obtaining more short-paired reads that extended into the regions where reads were previously un-mappable via an iterative fine-tuning process (Supplementary Figure S1). Four putative Pongamia homologs: ELF4, LCL1 (LHY/CCA1 like-1), PRR7, and TOC1 were found to have full coverage of the soybean circadian clock genes, and those genes are known to represent either morning or evening genes in the Arabidopsis circadian system (Table 1) [52-56].

The mapping results showed that ELF4, LCL1, PRR7, and TOC1 genes were represented in the Pongamia transcriptome. The full-length coding sequences of these genes were isolated from Pongamia leaf cDNA. Comparison of the coding sequences and their translated proteins with closely related legume species, soybean, and the model plant Arabidopsis (Table 2) showed that the Pongamia ELF4, LCL1, PRR7, and TOC1 exhibit higher sequence similarity to soybean, compared to Arabidopsis. PRR7 and TOC1 show over $90 \%$ similarity at nucleotide and $87 \%$ at protein level while ELF4 and LCL1 show over $80 \%$ similarity at nucleotide and $75 \%$ at protein level (Table 2).

\section{Characterization of Pongamia clock genes: Sequence and phylogenetic analyses and diurnal expression rhythms}

Based on protein alignment (Error! Reference source not found.a-Error! Reference source not found.a) and phylogenetic analyses (Error! Reference source not found.b-Error! Reference source not found.b), Pongamia ELF4, LCL1, PRR7, and TOC1 were found to be highly conserved among closely related 
legume species especially soybean, as well as other plant species such as model species Arabidopsis and rice. In addition, southern blot analyses showed that $L C L 1, P R R 7$, and TOC1 genes have single copy number in Pongamia genome whereas ELF4 has two (Error! Reference source not found.c Error! Reference source not found.c). Pongamia prefers long-day conditions for flowering. Our study on Pongamia ELF4, LCL1, PRR7, and TOC1 showed diurnal gene expression rhythms under longday conditions as indicated by qualitative (normal RT-PCR) and quantitative (qRT-PCR) analyses (Error! Reference source not found.d - Error! Reference source not found.d).

\section{EARLY FLOWERING 4 (ELF4)}

A comparison of proteins alignment showed that the Pongamia ELF4 protein possesses a highly conserved middle region; however, no known functional domain was found in this protein (Error! Reference source not found.a) [53,57,58]. Furthermore, the ELF4 phylogenetic tree has indicated the presence of two major clades, the ELF4 and ELF4-like clades (Error! Reference source not found.b). The putative Pongamia ELF4 protein, as expected, was found to belong in the ELF4 clade and is closely related with another legume (soybean, Medicago, pea) ELF4 proteins. Southern blot analysis of the ELF4 gene in Pongamia genome showed the presence of one band when digested with BamHI. However, two bands were observed when the Pongamia genome was digested with EcoRI (Error! Reference source not found.c). Additionally, both RT-PCR and qRT-PCR results of ELF4 expression (Error! Reference source not found.d) showed that ELF4 expression peaks at around $12 \mathrm{~h}$ after dawn. This is consistent with the fact that ELF4 is an evening gene and showing similar diurnal rhythm as AtELF4 [53,59,58,60].

\section{LATE ELONGATED HYPOCOTYL/CIRCADIAN CLOCK ASSOCIATED 1-like 1 (LCL1)}

Protein alignment of LCL1 showed that the N-terminal region is highly conserved and incorporates a Myb-type DNA binding domain (Fig. 2a) [61,62]. Several studies in Arabidopsis have shown that $L H Y$ and $C C A 1$ are hardly distinguishable as these genes have high sequence similarity, redundant functions, and are often co-expressed [63,64,54]. Two $L H Y$ - and CCA1-like genes, LCL1 and LCL2, were found in other plants including soybean $[65,33,66]$. Our study shows that the putative Pongamia $L C L 1$ is closely related to soybean $L C L 1$, but is indistinguishable from AtLHY and AtCCA1 (Fig. 2b). The digestion of the Pongamia genome using BamHI and HindIII in Southern blot analysis showed the presence of only one copy number of $L C L 1$ gene (Fig. 2c). Moreover, the expression level of $L C L 1$ was found to be consistent between the RT-PCR and the qRT-PCR results (Fig. 2d), showing that $L C L 1$ expression peaks at $4 \mathrm{~h}$ after dawn, begins to decrease upon approaching dusk ( $8 \mathrm{~h}$ after dawn), and begins to rise again just before dawn ( $24 \mathrm{~h}$ after dawn). This 
result is in agreement with $L C L 1$ being a morning gene and similar to pea, soybean and rice orthologous genes [67-69].

\section{TIMING OF CAB EXPRESSION 1 (TOC1)}

TOC1 is also known as PRR1, which belongs to the pseudo-response regulator (PRR) family, along with PRR3, PRR5, PRR7, and PRR9, which are known to be part of the circadian system [70,71]. The TOC1 protein includes a highly conserved pseudo-receiver (PR) domain in the N-terminus and the CONSTANS, CONSTANS-like and TOC1 (CCT) domain in the C-terminus (Error! Reference source not found.a). The former is known to be present in all PRR family proteins and is responsible for the transcriptional repression activity in TOC1 [72,73]. The latter, as the name suggests, is also found in CONSTANS (CO) and CONSTANS-like proteins and is responsible for DNA-binding activity [74,73]. Previous studies have found that differentiating between PRR5/PRR9 and PRR3/PRR7 is difficult, due to very close similarity [65,69]. Accordingly, three different clades of PRR1/TOC1, PRR5/PRR9, and PRR3/PRR7 were found to be present in the PRR phylogenetic tree, as shown in Error! Reference source not found.b and Error! Reference source not found.b. Furthermore, the phylogenetic analysis has determined that Pongamia TOC1 belongs to the PRR1/TOC1 clade and is closely related to TOC1 from other legume species (Fig. 3b). When genomic DNA is digested with BamHI, EcoRI and HindIII, results from southern blot analysis showed that there is one copy of TOC1 gene in the Pongamia genome (Error! Reference source not found.c). The expression level of TOC1 detected by RT-PCR and qRT-PCR was found to be very low as compared to other Pongamia clock genes analysed in this study. Nevertheless, qRT-PCR was able to show that TOC1 expression peaks at $20 \mathrm{~h}$ after dawn (Error! Reference source not found.d).

\section{PSEUDO-RESPONSE REGULATOR 7 (PRR7)}

Since PRR7 is part of the PRR family, it also contains a highly conserved PR domain in the Nterminus and a CCT domain in the C-terminus, as depicted in the protein alignment (Error! Reference source not found.a). Phylogenetic study of Pongamia PRR7 has placed this gene in the PRR3/PRR7 clade, showing it to be closely related to PRR3 than PRR7 (Error! Reference source not found.b). An analysis of the $P R R 7$ gene using Southern blot showed the presence of one copy when digested with BamHI and HindIII (Error! Reference source not found.c). Moreover, the RT-PCR result showed that PRR7 has similar expression levels at 8-, 12- and 16-h time points, but weaker expression at 4-h and 20-h time points. In contrast, qRT-PCR results showed that the $P R R 7$ expression has a broad peak around the 8-h time point, with slightly elevated expression at the 20-h time point (Error! Reference 
source not found.d). As PRR7 is known to be expressed in the morning in Arabidopsis [56,52,71], it is most likely that the peak observed at the 8-h time point corresponds to PRR7 expression. Expression rhythms of all four Pongamia clock genes investigated in the present study are summarized in Error! Reference source not found..

\section{Discussion}

\section{Conservation of circadian clock genes in Pongamia}

Circadian clock genes play important an role in precise integration of environmental signals required for flowering and also adaptation of plants to different geography locations (REF). However, circadian clock remains to be studied in tree legumes like Pongamia. Accordingly, the prerequisite for the analysis of the circadian system in Pongamia would be the identification of the key circadian clock genes that are responsible for the regulation of the circadian system. The mapping of the Pongamia transcriptome short-paired reads library [45] to the soybean circadian clock genes greatly facilitated the identification of four putative full-length Pongamia circadian clock genes in this study: ELF4, LCL1, PRR7, and TOC1 (Table 1). Therefore, this study has demonstrated that the depth of transcriptome obtained through next generation sequencing is a reliable tool for the identification of circadian clock genes, especially in non-model organisms, such as Pongamia, with limited genomic information. Consequently, the transcriptome library may be used in future studies for the identification of additional Pongamia genes involved in the flowering pathways and also other traits to improve seed yield specially traits linked to biofuel production.

The successful isolation of putative Pongamia circadian clock genes has served as an initial step toward the identification of components involved in the regulation of flowering time in Pongamia. The clock gene ELF4 is known to form an evening complex (EC) with ELF3 and LUX, which is required for the generation of circadian rhythms and hence regulation of output pathways such as flowering [75-77]. ELF4 belongs to a small plant kingdom-specific gene family, consists of other four gene members (ELFL1-ELFL4) [60,53,57]. Previous phylogenetic analysis has separated the ELF4 gene family into two clades: (1) ELF4 and ELFL1, and (2) ELFL2, ELFL3, and ELFL4 [57], which is in agreement with the findings of this study (Fig. 1b). Consequently, Pongamia ELF4 was found to be present in the ELF4/ELF4L1 clade and clustered together with other legume homologues (soybean, medicago and pea). The Southern blot analysis of ELF4 showed different results when digested with two different enzymes, BamHI and EcoRI, as shown in Fig. 1c. A possible explanation for this observation is that there are actually two copies of ELF4 gene located 
next to each other in the Pongamia genome. In fact, an EcoRI restriction site is present between the two ELF4 copies, which resulted in the presence of two bands. On the other hand, BamHI cutting site is not present in between the two ELF4 copies; hence only one band is obtained. Further analysis would need to be performed in order to determine which copy of ELF4 gene that has a significant role in the Pongamia circadian system.

Earlier studies have identified that CCA1 and LHY are MYB-like transcription factors that play pivotal roles in the morning loop of the central oscillator [54,63,64]. These transcription factors belong to the REVEILLE (RVE) family that consists of 11 proteins with high sequence similarity within the MYB-like domain [78]. In the soybean, GmLCL1 and GmLCL2 have been identified as part of the clock central components $[66,33,65]$. The putative Pongamia LCL1 and LCL2 genes have been successfully identified in this study (Table 1). Through Southern blot analysis, only one copy of $L C L 1$ gene is detected in the Pongamia genome. Since the MYB domain is known for DNA binding [79], those conserved domain could imply an important role in the DNA-binding activity of Pongamia LCL1.

PRR1/TOC1, PRR3, PRR5, PRR7, and PRR9 are members of PRR gene family, all of which are regulated by the circadian clock and have important roles in the regulation of the central oscillator [80,71,24,52]. In Arabidopsis, all five gene members of the $P R R$ family are expressed sequentially after dawn, in the following order: PRR9, PRR7, PRR5, PRR3, and PRR1/TOC1 [71,81,82]. Southern blot analysis of TOC1 and $P R R 7$ has found that both genes have one copy in the Pongamia genome. Moreover, the PRR protein family is known to have a conserved pseudoreceiver (PR) domain at the $\mathrm{N}$-terminal region and a CCT domain at the $\mathrm{C}$-terminal region $[70,83]$. Our study also showed that the PR and CCT domains are conserved in the putative Pongamia TOC1 and PRR7 proteins (Fig. 3a and Fig. 4a). Due to the highly conserved PR and CCT domains, it suggests that both Pongamia TOC1 and PRR7 might function in a similar way as Arabidopsis by repressing $L C L 1$ expression in the central oscillator [83,71,84].

\section{Expression patterns of Pongamia circadian clock genes}

The expression profiles of putative Pongamia ELF4, LCL1, PRR7, and TOC1, under long-day conditions, were addressed by both RT-PCR and qRT-PCR analysis in this study. Pongamia ELF4 expression peaks around $12 \mathrm{~h}$ after dawn, or around dusk (Fig. 1d). Pongamia $L C L 1$ expression peaks early in the morning, at around $4 \mathrm{~h}$ after dawn (Fig. 2d). The expression patterns of Pongamia PRR7 were observed to have a broad peak near the 8-h time point (Fig. 4d). On the contrary, the 
Pongamia TOC1 expression profile showed three different peaks at 0-, 12-, and 20-h time points (Fig. 3d). The peak of TOC1 expression at the 12-h time point (dusk) is also consistent with TOC1 being an evening gene $[84,70,55]$.

The morning loop genes $C C A 1$ and $L H Y$ are responsible for the activation of PRR9, PRR7, and PRR5, which can then form a negative feedback loop by binding to CCAl and LHY promoters, thereby inhibiting their expression [56,80]. In accordance, this study also showed that Pongamia $L C L 1$ and $P R R 7$ expressions peak together initially, but as the expression of PRR7 increases, LCL1 expression is repressed (Fig. 5). Moreover, CCAl and $L H Y$ from the morning loop have also been shown to form a connection to the evening loop by repressing the expression of TOC1, GI, ELF3, ELF4, and LUX in Arabidopsis [85,86,59,87]. Pongamia LCL1 expression is anti-phase to that of Pongamia ELF4 and TOC1 expression (Fig. 5). Additionally, the EC comprises ELF3, ELF4, and LUX, which have a repressive effect on TOC1, GI, LUX, and ELF4 expression [58,60]. Moreover, the EC also represses PRR9 to form another link with the morning loop [85,88,89]. Additionally, new studies have found that TOC1 as an evening gene is a transcriptional repressor of $C C A 1$ and $L H Y$, rather than an activator as previously conceived [90,84,52]. The expression levels of Pongamia LCL1 and TOC1 are inversely related to each other (Fig. 5). Accordingly, this study has successfully shown that Pongamia ELF4, LCL1, PRR7, and TOC1 are diurnally regulated in longday conditions and show feedback regulation in their expression patterns.

In addition, future studies may involve the investigation of Pongamia ELF4, LCL1, PRR7, and TOCI expression under short-day conditions to determine whether these genes can be entrained by a different photoperiod. ELF4, LCL1, PRR7, and TOC1 expression may also be studied under constant light or constant dark conditions to check if their expressions remain rhythmic in the absence of an external signal, i.e., true circadian rhythm.

\section{Implication of the circadian clock and flowering studies on Pongamia seed production}

It is well established in plants that proper matching of circadian rhythm with external cues will enhance photosynthesis and growth and thus improve survival and fitness [27,28]. In addition to this general finding, several studies have been carried out to investigate roles of the circadian clock in life cycle of plants especially crop plants such as cereals and legumes for their food and feed usage around the world. Cereals including maize, rice, and wheat accounted for most of the sources for human and animal food consumption. Maize microarray analysis has showed that $\sim 10 \%$ of 1444 transcripts showing circadian rhythms including genes involved in photosynthesis, carbohydrate 
metabolism, cell wall synthesis and flowering [91]. In barley, $P p d-H 1$ was found to be a major gene that control photoperiod responsiveness in barley. Positional cloning study has identified $\mathrm{Ppd}-\mathrm{Hl}$ as a clock orthologue of Arabidopsis PRR7, and a non-photoperiod responsive allele will allow springsown barley to build up higher grain yield and grain weight [92]. In wheat, PPD1 gene was also found to encode for PRR3 or PRR7 orhtologues where $p p d-1$ mutant flower 1 month later than wild type plants and PPDI is associated with most of the natural flowering variation in wheat $[93,94]$. A recent study on wheat also discovered loss-of-function in PHYC (PHYTOCHROME C) will cause altered expression of circadian and photoperiod genes and delay flowering in LD [95]. In the rice, QTL studies highlighted the importance of $H d l$, CONSTANCE (CO) orthologue, and Ghd7 which both are photoperiod pathways genes and colocalise with QTLs affect flowering time or number of grains per panicle $[96,97]$. Moreover, natural variation of cultivated rice flowering time has been shown to be associated with $H d 3 a$ (FT orthologue) promoter sequence, $H d 1$ protein sequence, and Ehd1 expression level [98,99]. Rice orthologue of clock gene ELF3 (OsELF3-1) was recently discovered to be involved in promoting rice flowering under short-day by activating Ehdl expression [100].

Legume seeds are second only to cereal crops as a source of human and animal food and include soybeans (Glycine max), garden peas (Pisum sativum), peanuts (Arachis hypogaea), and broad beans (Vicia faba). In the soybean, microarray and transcriptome analyses of developing seeds highlighted $1.8 \%$ of genes regulated by circadian rhythms, including genes involved in protein and fatty acid synthesis, lipid metabolism, and photosynthesis [101], suggesting the potential roles of the circadian clock in seed composition and development. A recent paper has showed that overexpressing AtBBX32, and its soybean homologues ( $G m B B X 52$ or GmBBX53) increases the yield gain in soybean by affecting a wide range of yield component parameters (such as flower number, pod number, and seed number) and extending the reproductive period [102]. Interestingly, microarray analysis of the transgenic soybean overexpressing AtBBX32 showed that most of the transcripts showed abundant changes at dawn and consistently soybean clock genes, GmLCL2 and GmTOC1 expression level were affected at dawn in the transgenic soybean [102] suggesting AtBBX32 might affect grain yield through modifying the light input to circadian clock near dawn [102]. Furthermore, a strong correlation was found in circadian rhythms of soybean photoreceptor gene, GmCRYla (CRYTOCHOROME 1a) with the latitudinal distribution of soybean cultivars and the photoperiodic control of flowering time [42]. In the pea, several early or late flowering mutants were found to be encoded by circadian clock genes including HR/ELF3, SN/LUX, and LATE1/GI [103,89,19]. In particular, flowering time variation in global pea 
germplasm was found to be controlled by a single $H R / E L F 3$ variant, which correlate with altered circadian rhythms and the reduced photoperiod responsiveness in the spring cultivars of pea [19].

Pongamia tree will start to flower after three to four years and flowering in the southern hemisphere occurs around November/December. After flowering, the seed takes about 10 months to mature and each seed weigh around $1.8 \mathrm{~g}$ with approximately $40 \%$ oil content $[12,22,7]$. Pongamia is an out-crossing species through insect-mediated pollination, pollination of Pongamia mainly rely on several bee species through floral nectar sources [104]. Interestingly, nectar secretion and flower opening was found to be regulated by circadian clock to increase the maximum chances of pollination by timed to potential pollinator activity [105-107]. Hence, this paper specifically focuses on the circadian clock system, which is part of the photoperiod pathway $[108,24,65,109,75]$, for its role as one of the key regulators of flowering time. By deciphering the molecular basis of flowering time control, we could eventually manipulate the transition from vegetation to flowering stage for shorter vegetative period and prolonged flowering stage, which will lead to the extended period of seed production in order to increase raw material of biofuel production. In addition, the identification and analyses of the genes involved in the Pongamia circadian system, as well as in other developmental pathways, has the potential to facilitate the development of Pongamia cultivars that are suitable to be grown in wide range of climates with the potential of manipulating adaptation of Pongamia plant to different photoperiod condition. This will have an implication for expanding the range of geographical areas for the large-scale production of Pongamia trees for biodiesel production. Together, extending our knowledge regarding the function of circadian clock genes and the relationship with flowering control in Pongamia is key to regulate the process of flowering and improve seed yield in order to make Pongamia a sustainable sources for biofuel production.

\section{Acknowledgement}

This work was supported by the Australian Research Council in the form of the ARC Centre of Excellence for Integrative Legume Research (CE0348212) and McKenzie Postdoctoral Fellowship by the University of Melbourne. 


\section{Figures and Tables Legends}

Table 1 Mapping results of the Pongamia transcriptome library to the soybean circadian clock genes. The putative Pongamia circadian clock genes that covered the full length soybean reference genes are highlighted in dark blue and the genes that were being studied further are shown in bold letters.

Table 2 Sequences similarity of Pongamia nucleotides and proteins with soybean and Arabidopsis

Fig. 1 a ELF4 protein sequence alignment between Arabidopsis thaliana (At), Glycine max (Gm), Millettia pinnata (Mp), Medicago truncatula (Mt) and Pisum sativum (Ps). The shaded regions represent $100 \%$ similarity (black), $80-99 \%$ similarity (dark grey with white font) and $60-79 \%$ similarity (light grey with black font). At ELF4 (NP_565922.1), Gm ELF4b (XP_003537487.1), Mp ELF4, Mt ELF4a (AFK36717.1), Ps ELF4 (AAX47177.2). b Phylogenetic tree of putative Pongamia ELF4 protein and other plant species were constructed based on their protein alignments. The tree is drawn to given scale and the bootstrap values are shown at each node. At, Arabidopsis thaliana $($ AtELF4 = NP_565922.1, AtELFL1 = NP_180556.1, AtELFL2 = NP_565044.1, AtELFL3 = NP_565334.1, AtELFL4 = NP_564024.1); Cr, Chlamydomonas reinhardtii (CrELF4 = XP_001689467.1); Gm, Glycine $\max$ (GmELF4a = NP_001236861.1, GmELF4b = XP_003537487.1, GmELF4c = XP_003552375.1, GmELF4d = NP_001236892.1); Hv, Hordeum vulgare (HvELF4 = BAK04623.1); Mc, Mesembryanthemum crystallinum (McELF4 = AAQ73526.1; Mp, Millettia pinnata; Mt, Medicago truncatula (MtELF4a = AFK36717.1, MtELF4b = XP_003627239.1 , MtELF4d = AFK49629.1) Os, Oryza sativa (OsELF = AAD27669.1); Ppa, Physcomitrella patens (PpaELF4 = XP_001774658.1); Pp, Prunus persica (PpELF4 = EMJ19798.1); Ps, Pisum sativum (PsELF4 = AAX47177.2); Pta, Pinus taeda (PtaELF4 = ACK56119.1); Pt, Populus trichocarpa $(\mathrm{PtELF}=\mathrm{XP}$ _002311221.1); Sl, Solanum lycopersicum $\left(\right.$ SlELF $=$ XP_004241125.1); Vv, Vitis Vinifera $\left(V v E L F=X P \_002270733.1\right)$. c Southern blot analysis of ELF4 digested with BamHI and EcoRI. d Expression pattern of putative Pongamia ELF4 under long day conditions (18 hours light : 6 hours dark) in a 24 hour period. qRT-PCR and RTPCR results of ELF4 expression normalized against Cons7 expression; the data from three replicates have been averaged. Each time point corresponds to the number of hours after lights on, i.e. the number of hours after dawn.

Fig. 2 a LCL1 protein alignment between Arabidopsis thaliana (At), Glycine max (Gm), Millettia pinnata $(\mathrm{Mp})$ and Pisum sativum (Ps). The region corresponding to the Myb DNA binding domain is indicated. The shaded regions represent $100 \%$ similarity (black), $80-99 \%$ similarity (dark grey with white font) and $60-79 \%$ similarity (light grey with black font). At LHY (NP_001077437.1), Gm LCL1 (NP_001235187.1), Mp LCL1, Ps MYB1 (AAX33630.1). b Phylogenetic tree of putative Pongamia LCL1 protein with other plant species were constructed based on their protein alignments. The tree is drawn to given scale and the bootstrap values are shown at each node. At, Arabidopsis thaliana (AtCCA1 = NP_850460.1, AtLHY = NP_001077437.1); Cs, Castanea sativa $(\mathrm{CsLHY}=\mathrm{AAU} 20773.1) ; \mathrm{Gm}$, Glycine $\max (\mathrm{GmLCL} 1=\mathrm{NP}$ 001235187.1, GmLCL2 = NP_001236400.1); Lg, Lemna gibba (LgLHYH1 = BAD97870, LgLHYH2 = BAD97871); Lp, Lemna paucicostata (LpLHYH1 = BAD97866, LpLHYH2 = BAD97867); Mc, Mesembryanthemum crystallinum $(\mathrm{McCCA} 1=\mathrm{AAQ73524}) ; \mathrm{Mj}$, Mirabilis jalapa $(\mathrm{MjLHY}=$ ACL81163); Mp, Millettia pinnata ; Mt, Medicago truncatula (MtCCA1a = XP_003626618.1, MtMYBa = XP_003600632.1, MtMYBb = XP_003616176.1) Os, Oryza sativa (OsCCA1 = NP_001061032); Pn, Populus nigra (PnLHY1 = BAH09382, PnLHY2 = BAH09383); Ppa, Physcomitrella patens $($ PpaCCA1a $=$ BAI39991, PpaCCA1b = BAI39992)s; Ps, Pisum sativum 
$(\mathrm{PsMYB} 1=\mathrm{AAX} 33630.1$, PsMyb2 = AAX33631.1); Pt, Populus trichocarpa (PtMYB = XP_002320238.1); Pv, Phaseolus vulgaris (PvLHY = CAD12767.2); Rc, Ricinus communis $($ RcMYB = XP_002515093.1); Sb, Sorghum bicolour (SbMYB = XP_002443890.1); S1, Solanum lycopersicum $\left(\right.$ SILHY = XP_004248416.1); Vv, Vitis Vinifera $\left(V v M Y B=X P \_002267720.1\right) ; Z m$, Zea mays (ZmLHY = NP_001147482.1). c Southern blot analysis of LCLI digested with BamHI and HindIII. d Expression pattern of putative Pongamia LCLI under long day conditions (18 hours light : 6 hours dark) in a 24 hour period. qRT-PCR and RT-PCR results of LCL1 expression normalized against Cons 7 expression; the data from three replicates have been averaged. Each time point corresponds to the number of hours after lights on, i.e. the number of hours after dawn.

Fig. 3 a TOC1 protein alignment between Arabidopsis thaliana (At), Glycine max (Gm), Millettia pinnata $(\mathrm{Mp})$ and Pisum sativum (Ps). The regions corresponding to the PR and CCT domains are indicated. The shaded regions represent $100 \%$ similarity (black), $80-99 \%$ similarity (dark grey with white font) and $60-79 \%$ similarity (light grey with black font). At PRR1 (NP_200946.1), Gm TOC1 (NP_001235202.1), Mp TOC1, Ps TOC1 (AAX47178.1). b Phylogenetic tree of putative Pongamia TOC1 protein with other PRR proteins from different plant species were constructed based on their protein alignments. The tree is drawn to given scale and the bootstrap values are shown at each node. At, Arabidopsis thaliana (AtPRR1 = NP_200946.1, AtPRR3 = NP_568919.1, AtPRR5 = NP_568446.1, AtPRR7 = NP_568107.1, AtPRR9 = NP_566085.1); Cs, Castanea sativa $(\mathrm{CsPRR} 7=\mathrm{ABV53463.1}$, CsTOC1 = AAU20772.1); Gm, Glycine max (GmPRR7 = XP_003536977.1, GmTOC1 = NP_001235202.1); Hv, Hordeum vulgare $(\mathrm{HvPPd}-\mathrm{H} 1=$ AAY17586.1); Lg, Lemna gibba (LgPRR-H37 = BAE72700.1, LgPRR-H59 = BAE72701.1, LgPRR-H95 = BAE72702.1); Lp, Lemna paucicostata $($ LpPRR-H37 = BAE72697.1, LpPRR-H59 = BAE72698.1, LpPRR-H95 = BAE72699.1); Mp, Millettia pinnata ;Mt, Medicago truncatula $($ MtPRR73a $=$ XP_003606528.1); Os, Oryza sativa $($ OsPRR1 = BAD38854.1, OsPRR37 = BAD38858.1, OsPRR73 = BAD38859.1, OsPRR95 = BAD38857); Ps, Pisum sativum (PsPRR37 = ACU42263.2, PsTOC1 = AAX47178.1); Pt, Populus trichocarpa (PtPRR5 = XP_002320232.1, PtPRR7 = XP_002311123.1); Zm, Zea mays (ZmPRR95 = NP_001151536.1). c Southern blot analysis of TOCl digested with BamHI, EcoRI and HindIII. d Expression pattern of putative Pongamia TOC1 under long day conditions (18 hours light : 6 hours dark) in a 24 hour period. qRTPCR and RT-PCR results of TOC1 expression normalized against Cons 7 expression; the data from three replicates have been averaged. Each time point corresponds to the number of hours after lights on, i.e. the number of hours after dawn.

Fig. 4 a PRR7 protein alignment between Arabidopsis thaliana (At), Glycine max (Gm), Millettia pinnata $(\mathrm{Mp})$, Medicago truncatula $(\mathrm{Mt})$ and Pisum sativum $(\mathrm{Ps})$. The regions corresponding to the PR and CCT domains are indicated. The shaded regions represent $100 \%$ similarity (black), $80-99$ $\%$ similarity (dark grey with white font) and $60-79 \%$ similarity (light grey with black font). At PRR7 (NP_568107.1), Gm PRR7 (XP_003536977.1), Mp PRR7, Mt PRR73a (XP_003606528.1), Ps PRR37 (ACU42263.2). b Phylogenetic tree of putative Pongamia PRR7 protein with other PRR proteins from different plant species were constructed based on their protein alignments. The tree is drawn to given scale and the bootstrap values are shown at each node. At, Arabidopsis thaliana $($ AtPRR1 = NP_200946.1, AtPRR3 = NP_568919.1, AtPRR5 = NP_568446.1, AtPRR7 = NP_568107.1, AtPRR9 = NP_566085.1); Cs, Castanea sativa $(\mathrm{CsPRR7}=\mathrm{ABV53463.1,} \mathrm{CsTOC1}$ = AAU20772.1); Gm, Glycine max (GmPRR7 = XP_003536977.1, GmTOC1 = NP_001235202.1); $\mathrm{Hv}$, Hordeum vulgare $(\mathrm{HvPPd}-\mathrm{H} 1=\mathrm{AAY} 17586.1)$; $\mathrm{Lg}$, Lemna gibba (LgPRR-H37 = BAE72700.1, LgPRR-H59 = BAE72701.1, LgPRR-H95 = BAE72702.1); Lp, Lemna paucicostata (LpPRR-H37 = BAE72697.1, LpPRR-H59 = BAE72698.1, LpPRR-H95 = BAE72699.1); Mp, Millettia pinnata; Mt, Medicago truncatula (MtPRR73a = XP_003606528.1); Os, Oryza sativa 
$($ OsPRR1 = BAD38854.1, OsPRR37 = BAD38858.1, OsPRR73 = BAD38859.1, OsPRR95 = BAD38857); Ps, Pisum sativum (PsPRR37 = ACU42263.2, PsTOC1 = AAX47178.1); Pt, Populus trichocarpa (PtPRR5 = XP_002320232.1, PtPRR7 = XP_002311123.1); Zm, Zea mays (ZmPRR95 = NP_001151536.1). c Southern blot analysis of PRR7 digested with BamHI and HindIII. d Expression pattern of putative Pongamia $P R R 7$ under long day conditions (18 hours light : 6 hours dark) in a 24 hour period. qRT-PCR and RT-PCR results of $P R R 7$ expression normalized against Cons 7 expression; the data from three replicates have been averaged. Each time point corresponds to the number of hours after lights on, i.e. the number of hours after dawn.

Fig. 5 Expression pattern of putative Pongamia ELF4, LCL1, PRR7 and TOC1 as determined by qRT-PCR under long-day conditions (18 hours light : 6 hours dark) in a 24 hour period. To clarify the profiles, the maximum level of each transcript was taken as 1. 


\section{Tables and Figures}

Table 1 Mapping results of the Pongamia Transcriptome library to the soybean circadian clock genes. The putative Pongamia circadian clock genes that covered the full-length soybean reference genes are highlighted in dark blue and the genes that were being studied further are shown in bold letters.

\begin{tabular}{|c|c|c|c|}
\hline $\begin{array}{c}\text { Circadian } \\
\text { Clock } \\
\text { Genes }\end{array}$ & $\begin{array}{l}\text { Soybean Gene } \\
\text { Identifiers }\end{array}$ & $\begin{array}{c}\text { Coverage } \\
(\%)\end{array}$ & Reference \\
\hline \multirow[t]{4}{*}{$\mathrm{CO}$} & Glyma08g28370 & 95 & \multirow{4}{*}{$\begin{array}{l}\text { Jung et al. } \\
\text { (2012) }\end{array}$} \\
\hline & Glyma13g07030 & 45 & \\
\hline & Glyma18g51320 & 100 & \\
\hline & Glyma19g05170 & 45 & \\
\hline \multirow[t]{3}{*}{$E L F 3$} & Glyma04g05280 & 95 & \multirow{3}{*}{$\begin{array}{l}\text { Jung et al. } \\
\text { (2012) }\end{array}$} \\
\hline & Glyma14g10530 & 65 & \\
\hline & Glyma17g34980 & 45 & \\
\hline \multirow[t]{2}{*}{ ELF4 } & Glyma11g35270 & 100 & \multirow{2}{*}{$\begin{array}{c}\text { Thakare et al. } \\
\text { (2010) }\end{array}$} \\
\hline & Glyma18g03130 & 100 & \\
\hline$G I$ & Glyma10g36600 & 100 & $\begin{array}{c}\text { Thakare et al. } \\
\text { (2010) }\end{array}$ \\
\hline$L C L 1$ & Glyma16g01980 & 100 & $\begin{array}{c}\text { Thakare et al. } \\
(2010)\end{array}$ \\
\hline$L C L 2$ & Glyma03g42260 & 100 & $\begin{array}{c}\text { Thakare et al. } \\
(2010)\end{array}$ \\
\hline$L U X$ & Glyma11g14490 & 75 & $\begin{array}{c}\text { Liew } \\
\text { (unpublished } \\
\text { data) }\end{array}$ \\
\hline \multirow[t]{2}{*}{ PRR5 } & Glyma04g40640 & 100 & \multirow{2}{*}{$\begin{array}{c}\text { Jung et al. } \\
\text { (2012) }\end{array}$} \\
\hline & Glyma06g14150 & 100 & \\
\hline PRR7 & Glyma10g05520 & 100 & $\begin{array}{c}\text { Jung et al. } \\
\text { (2012) }\end{array}$ \\
\hline TOC1 & Glyma06g21120 & 100 & $\begin{array}{c}\text { Thakare et al. } \\
\text { (2010) }\end{array}$ \\
\hline
\end{tabular}


1 Table 2 Sequences similarity of Pongamia nucleotides and proteins with soybean and Arabidopsis

\begin{tabular}{|c|c|c|c|c|c|c|c|c|c|}
\hline \multirow{2}{*}{$\begin{array}{l}\text { Pongamia } \\
\text { Gene }\end{array}$} & \multirow{2}{*}{$\begin{array}{c}\text { Soybean Gene } \\
\text { ID }\end{array}$} & \multirow{2}{*}{$\begin{array}{c}\text { Arabidopsis } \\
\text { Gene ID }\end{array}$} & \multirow{2}{*}{$\begin{array}{l}\text { Number of } \\
\text { Nucleotides }\end{array}$} & \multicolumn{2}{|c|}{$\begin{array}{c}\text { Nucleotides Similarity } \\
(\%)\end{array}$} & \multirow{2}{*}{$\begin{array}{l}\text { Pongamia } \\
\text { Protein }\end{array}$} & \multirow{2}{*}{$\begin{array}{c}\text { Number of } \\
\text { Amino } \\
\text { Acid }\end{array}$} & \multicolumn{2}{|c|}{$\begin{array}{c}\text { Amino Acid Similarity } \\
(\%)\end{array}$} \\
\hline & & & & Soybean & Arabidopsis & & & Soybean & Arabidopsis \\
\hline ELF4 & Glyma11g35270 & At2g40080 & 354 & 80.2 & 62.6 & ELF4 & 117 & 75.8 & 57.7 \\
\hline$L C L 1$ & Glyma16g01980 & At1g01060 & 2305 & 87.9 & 58.4 & LCL1 & 746 & 82.8 & 46.5 \\
\hline PRR7 & Glyma10g05520 & At5g02810 & 2436 & 91.3 & 60.0 & PRR7 & 755 & 87.1 & 47.8 \\
\hline TOC1 & Glyma06g21120 & At5g61380 & 1692 & 90.2 & 62.2 & TOC1 & 563 & 88.7 & 49.8 \\
\hline
\end{tabular}




\section{References}

1. BP Statistical Review of World Energy 2013. (2013). http://www.bp.com/en/global/corporate/aboutbp/energy-economics/statistical-review-of-world-energy.html. Accessed 20 June 2014

2. McMichael AJ, Powles JW, Butler CD, Uauy R (2007) Food, livestock production, energy, climate change, and health. The lancet 370 (9594):1253-1263

3. Murray J, King D (2012) Climate policy: Oil's tipping point has passed. Nature 481 (7382):433-435. doi:10.1038/481433a

4. Murphy HT, O'Connell DA, Seaton G, Raison RJ, Rodriguez LC, Braid AL, Kriticos DJ, Jovanovic T, Abadi A, Betar M (2012) A common view of the opportunities, challenges, and research actions for Pongamia in Australia. BioEnergy Research 5 (3):778-800

5. Biswas B, Scott PT, Gresshoff PM (2011) Tree legumes as feedstock for sustainable biofuel production: Opportunities and challenges. J Plant Physiol 168 (16):1877-1884. doi:10.1016/j.jplph.2011.05.015

6. Jensen ES, Peoples MB, Boddey RM, Gresshoff PM, Hauggaard-Nielsen H, Alves BJ, Morrison MJ (2012) Legumes for mitigation of climate change and the provision of feedstock for biofuels and biorefineries. A review. Agron Sustain Dev 32 (2):329-364

7. Scott PT, Pregelj L, Chen N, Hadler JS, Djordjevic MA, Gresshoff PM (2008) Pongamia pinnata: an untapped resource for the biofuels industry of the future. BioEnergy Research 1 (1):2-11

8. Tomar O, Gupta R (1985) Performance of some forest tree species in saline soils under shallow and saline water-table conditions. Plant Soil 87 (3):329-335

9. Patil S, Hebbara M, Devarnavadagi S (1996) Screening of multipurpose trees for saline vertisols and their bioameliorative effects. Annals of Arid Zone 35 (1):57-60

10. Arpiwi NL, Yan G, Barbour EL, Plummer JA, Watkin E (2012) Phenotypic and genotypic characterisation of root nodule bacteria nodulating Millettia pinnata (L.) Panigrahi, a biodiesel tree. Plant Soil:1-15

11. Kant P, Wu S (2011) The extraordinary collapse of Jatropha as a global biofuel. Environ Sci Technol 45 (17):7114-7115. doi:10.1021/es201943v

12. Kazakoff SH, Gresshoff PM, Scott PT (2011) Pongamia pinnata, a sustainable feedstock for biodiesel production. Energy crops Royal Society of Chemistry, London:233-254

13. Coupland G (1997) Regulation of flowering by photoperiod in Arabidopsis. Plant Cell Environ 20 (6):785789

14. Abou-Elwafa SF, Büttner B, Chia T, Schulze-Buxloh G, Hohmann U, Mutasa-Göttgens E, Jung C, Müller AE (2011) Conservation and divergence of autonomous pathway genes in the flowering regulatory network of Beta vulgaris. J Exp Bot 62 (10):3359-3374. doi:10.1093/jxb/erq321

15. Cober ER, Tanner JW, Voldeng HD (1996) Genetic control of photoperiod response in early-maturing, near-isogenic soybean lines. Crop Sci 36 (3):601-605

16. Faure S, Turner AS, Gruszka D, Christodoulou V, Davis SJ, von Korff M, Laurie DA (2012) Mutation at the circadian clock gene EARLY MATURITY 8 adapts domesticated barley (Hordeum vulgare) to short growing seasons. Proc Natl Acad Sci U S A 109 (21):8328-8333. doi:10.1073/pnas.1120496109

17. Hsu JC, Hamner KC (1967) Studies of the involvement of an endogenous rhythm in the photoperiodic response of Hyoscyamus niger. Plant Physiol 42 (5):725-730

18. Takahashi Y, Shomura A, Sasaki T, Yano M (2001) Hd6, a rice quantitative trait locus involved in photoperiod sensitivity, encodes the alpha subunit of protein kinase CK2. Proc Natl Acad Sci U S A 98 (14):7922-7927

19. Weller JL, Liew LC, Hecht VFG, Rajandran V, Laurie RE, Ridge S, Wenden B, Vander Schoor JK, Jaminon O, Blassiau C, Dalmais M, Rameau C, Bendahmane A, Macknight RC, Lejeune-Hénaut I (2012) A conserved molecular basis for photoperiod adaptation in two temperate legumes. Proc Natl Acad Sci U S A 109:21158-21163. doi:10.1073/pnas.1207943110

20. Kukade SA, Tidke JA (2013) STUDIES ON POLLINATION AND REPRODUCTIVE BIOLOGY OF PONGAMIA PINNATA L.(FABACEAE). Indian Journal of Fundamental and Applied Life Sciences 3 (1):149-155

21. Jiang Q, Yen S-H, Stiller J, Edwards D, Scott PT, Gresshoff PM (2012) Genetic, Biochemical, and Morphological Diversity of the Legume Biofuel Tree Pongamia pinnata. Journal of Plant Genome Sciences 1 (3):54-67 
22. Kazakoff SH, Imelfort M, Edwards D, Koehorst J, Biswas B, Batley J, Scott PT, Gresshoff PM (2012) Capturing the Biofuel Wellhead and Powerhouse: The Chloroplast and Mitochondrial Genomes of the Leguminous Feedstock Tree Pongamia pinnata. PLoS One 7 (12):e51687

23. Gardner M, Hubbard K, Hotta C, Dodd A, Webb A (2006) How plants tell the time. Biochem J 397:15-24

24. Nagel DH, Kay SA (2012) Complexity in the wiring and regulation of plant circadian networks. Curr Biol 22 (16):R648-657. doi:10.1016/j.cub.2012.07.025

25. Stratmann T, Más P Chromatin, photoperiod and the Arabidopsis circadian clock: a question of time. In: Seminars in cell \& developmental biology, 2008. vol 6. Elsevier, pp 554-559

26. Nakahata Y, Grimaldi B, Sahar S, Hirayama J, Sassone-Corsi P (2007) Signaling to the circadian clock: plasticity by chromatin remodeling. Curr Opin Cell Biol 19 (2):230-237

27. Dodd AN, Salathia N, Hall A, Kévei E, Tóth R, Nagy F, Hibberd JM, Millar AJ, Webb AA (2005) Plant circadian clocks increase photosynthesis, growth, survival, and competitive advantage. Sci Signal 309 (5734):630

28. Green RM, Tingay S, Wang Z-Y, Tobin EM (2002) Circadian rhythms confer a higher level of fitness to Arabidopsis plants. Plant Physiol 129 (2):576-584

29. Michael TP, Salome PA, Yu HJ, Spencer TR, Sharp EL, McPeek MA, Alonso JM, Ecker JR, McClung CR (2003) Enhanced fitness conferred by naturally occurring variation in the circadian clock. Science 302 (5647):1049-1053

30. Caicedo AL, Stinchcombe JR, Olsen KM, Johanna Schmitt, Purugganan MD (2004) Epistatic interaction between Arabidopsis $F R I$ and $F L C$ flowering time genes generates a latitudinal cline in a life history trait. Proc Natl Acad Sci U S A 101:15670-15675

31. Faure S, Turner AS, Gruszka D, Christodoulou V, Davis SJ, von Korff M, Laurie DA (2012) Mutation at the circadian clock gene EARLY MATURITY 8 adapts domesticated barley (Hordeum vulgare) to short growing seasons. Proc Natl Acad Sci U S A. doi:10.1073/pnas.1120496109

32. Slotte T, Holm K, McIntyre LM, Lagercrantz U, Lascoux M (2007) Differential expression of genes important for adaptation in Capsella bursa-pastoris (Brassicaceae). Plant Physiol 145 (1):160-173. doi:10.1104/pp.107.102632

33. Jung $\mathrm{CH}$, Wong $\mathrm{CE}$, Singh MB, Bhalla PL (2012) Comparative genomic analysis of soybean flowering genes. PLoS One 7 (6):e38250. doi:10.1371/journal.pone.0038250

34. Wong CE, Singh MB, Bhalla PL (2013) The dynamics of soybean leaf and shoot apical meristem transcriptome undergoing floral initiation process. PLOS ONE 8 (6):e65319

35. Jiang B, Yue Y, Gao Y, Ma L, Sun S, Wu C, Hou W, Lam H-M, Han T (2013) GmFT2a polymorphism and maturity diversity in soybeans. PLoS ONE 8 (10):e77474

36. Na X, Jian B, Yao W, Wu C, Hou W, Jiang B, Bi Y, Han T (2013) Cloning and functional analysis of the flowering gene GmSOC1-like, a putative SUPPRESSOR OF OVEREXPRESSION CO1/AGAMOUS-LIKE 20 (SOC1/AGL20) ortholog in soybean. Plant Cell Rep:1-11

37. Wong CE, Khor SY, Bhalla PL, Singh MB (2011) Novel spatial expression of soybean WUSCHEL in the incipient floral primordia. Planta 233:553-560

38. Wong CE, Singh MB, Bhalla PL (2013) Spatial expression of CLAVATA3 in the shoot apical meristem suggests it is not a stem cell marker in soybean. J Exp Bot 64 (18):5641-5649. doi:doi: 10.1093/jxb/ert341

39. Wong CE, Singh MB, Bhalla PL (2013) Novel members of the AGAMOUS LIKE 6 subfamily of MIKCC-type MADS-box genes in soybean. BMC Plant Biol 13 (1):105

40. Wu F, Price BW, Haider W, Seufferheld G, Nelson R, Hanzawa Y (2014) Functional and Evolutionary Characterization of the CONSTANS Gene Family in Short-Day Photoperiodic Flowering in Soybean. PloS one 9 (1):e85754

41. Xia Z, Watanabe S, Yamada T, Tsubokura Y, Nakashima H, Zhai H, Anai T, Sato S, Yamazaki T, Lü S, Wu H, Tabata S, Harada K (2012) Positional cloning and characterization reveal the molecular basis for soybean maturity locus E1 that regulates photoperiodic flowering. Proc Natl Acad Sci U S A 109 (32):E2155E2164. doi:10.1073/pnas.1117982109

42. Zhang Q, Li H, Li R, Hu R, Fan C, Chena F, Wang Z, Liu X, Fu Y, Lin C (2008) Association of the circadian rhythmic expression of GmCRY1a with a latitudinal cline in photoperiodic flowering of soybean. Proc Natl Acad Sci U S A 105:21028-21033 
43. Liew LC, Singh MB, Bhalla PL (2013) An RNA-Seq Transcriptome Analysis of Histone Modifiers and RNA Silencing Genes in Soybean during Floral Initiation Process. PloS one 8 (10):e77502

44. Gepts P, Beavis WD, Brummer EC, Shoemaker RC, Stalker HT, Weeden NF, Young ND (2005) Legumes as a model plant family. Genomics for food and feed report of the cross-legume advances through genomics conference. Plant Physiol 137 (4):1228-1235

45. Huang J, Lu X, Yan H, Chen S, Zhang W, Huang R, Zheng Y (2012) Transcriptome characterization and sequencing-based identification of salt-responsive genes in Millettia pinnata, a semi-mangrove plant. DNA Res 19 (2):195-207. doi:10.1093/dnares/dss004

46. Goodstein DM, Shu S, Howson R, Neupane R, Hayes RD, Fazo J, Mitros T, Dirks W, Hellsten U, Putnam N, Rokhsar DS (2012) Phytozome: a comparative platform for green plant genomics. Nucleic Acids Res 40 (Database issue):D1178-1186. doi:10.1093/nar/gkr944

47. Drummond A, Ashton B, Buxton S, Cheung M, Cooper A, Duran C, Field M, Heled J, Kearse M, Markowitz S, Moir R, Stones-Havas S, Sturrock S, Thierer T, A W (2013) Geneious v6 (http://www.geneious.com/) Biomatters Ltd, Auckland, New Zealand

48. Rogers SO, Bendich AJ (1994) Extraction of total cellular DNA from plants, algae and fungi. In: Plant molecular biology manual. Springer, pp 183-190

49. Southern E (2006) Southern blotting. Nat Protoc 1 (2):518-525

50. Thibivilliers S, Joshi T, Campbell K, Scheffler B, Xu D, Cooper B, Nguyen H, Stacey G (2009) Generation of Phaseolus vulgaris ESTs and investigation of their regulation upon Uromyces appendiculatus infection. BMC Plant Biol 9 (1):46

51. Libault M, Thibivilliers S, Bilgin D, Radwan O, Benitez M, Clough S, Stacey G (2008) Identification of four soybean reference genes for gene expression normalization. The Plant Genome 1 (1):44-54

52. Pokhilko A, Fernández AP, Edwards KD, Southern MM, Halliday KJ, Millar AJ (2012) The clock gene circuit in Arabidopsis includes a repressilator with additional feedback loops. Mol Syst Biol 8:574

53. Doyle MR, Davis SJ, Bastow RM, McWatters HG, Kozma-Bognár L, Nagy F, Millar AJ, Amasino RM (2002) The ELF4 gene controls circadian rhythms and flowering time in Arabidopsis thaliana. Nature 419 (6902):74-77

54. Alabadi D, Yanovsky MJ, Más P, Harmer SL, Kay SA (2002) Critical Role for CCA1 and LHY in Maintaining Circadian Rhythmicity in Arabidopsis. Curr Biol 12 (9):757-761

55. Alabadi D, Oyama T, Yanovsky MJ, Harmon FG, Mas P, Kay SA (2001) Reciprocal regulation between TOC1 and LHY/CCA1 within the Arabidopsis circadian clock. Sci Signal 293 (5531):880

56. Farré EM, Harmer SL, Harmon FG, Yanovsky MJ, Kay SA (2005) Overlapping and distinct roles of $P R R 7$ and PRR9 in the Arabidopsis circadian clock. Curr Biol 15 (1):47-54

57. Khanna R, Kikis EA, Quail PH (2003) EARLY FLOWERING 4 functions in phytochrome B-regulated seedling de-etiolation. Plant Physiol 133 (4):1530-1538

58. Nusinow DA, Helfer A, Hamilton EE, King JJ, Imaizumi T, Schultz TF, Farré EM, Kay SA (2011) The ELF4ELF3-LUX complex links the circadian clock to diurnal control of hypocotyl growth. Nature 475 (7356):398-402

59. Kikis EA, Khanna R, Quail PH (2005) ELF4 is a phytochrome-regulated component of a negative-feedback loop involving the central oscillator components CCA1 and LHY. Plant J 44 (2):300-313

60. Kolmos E, Nowak M, Werner M, Fischer K, Schwarz G, Mathews S, Schoof H, Nagy F, Bujnicki JM, Davis SJ (2009) Integrating ELF4 into the circadian system through combined structural and functional studies. HFSP J 3 (5):350-366

61. Schaffer R, Ramsay N, Samach A, Corden S, Putterill J, Carré IA, Coupland G (1998) The late elongated hypocotyl mutation of Arabidopsis disrupts circadian rhythms and the photoperiodic control of flowering. Cell 93 (7):1219-1229

62. Wang Z-Y, Tobin EM (1998) Constitutive expression of the CIRCADIAN CLOCK ASSOCIATED 1 (CCA1) gene disrupts circadian rhythms and suppresses its own expression. Cell 93 (7):1207-1218

63. Mizoguchi T, Wheatley K, Hanzawa Y, Wright L, Mizoguchi M, Song H-R, Carré IA, Coupland G (2002) LHY and CCA1 Are Partially Redundant Genes Required to Maintain Circadian Rhythms in Arabidopsis. Dev Cell 2 (5):629-641

64. Green RM, Tobin EM (2002) The role of CCA1 and LHY in the plant circadian clock. Dev Cell 2 (5):516518 
65. Thakare D, Kumudini S, Dinkins RD (2010) Expression of flowering-time genes in soybean E1 nearisogenic lines under short and long day conditions. Planta 231 (4):951-963. doi:10.1007/s00425-010$1100-6$

66. Liu H, Wang H, Gao P, Xu J, Xu T, Wang J, Wang B, Lin C, Fu YF (2009) Analysis of clock gene homologs using unifoliolates as target organs in soybean (Glycine max). J Plant Physiol 166 (3):278-289. doi:10.1016/j.jplph.2008.06.003

67. Liew LC, Hecht V, Laurie RE, Knowles CL, Vander Schoor JK, Macknight RC, Weller JL (2009) DIE NEUTRALIS and LATE BLOOMER 1 contribute to regulation of the pea circadian clock. Plant Cell 21:31983211. doi:10.1105/tpc.109.067223

68. Liu H, Wang H, Gao P, Xü J, Xü T, Wang J, Wang B, Lin C, Fu Y-F (2009) Analysis of clock gene homologs using unifoliolates as target organs in soybean (Glycine max). J Plant Physiol 166 (3):278-289

69. Murakami M, Tago Y, Yamashino T, Mizuno T (2007) Comparative overviews of clock-associated genes of Arabidopsis thaliana and Oryza sativa. Plant Cell Physiol 48 (1):110-121

70. Strayer C, Oyama T, Schultz TF, Raman R, Somers DE, Más P, Panda S, Kreps JA, Kay SA (2000) Cloning of the Arabidopsis clock gene TOC1, an autoregulatory response regulator homolog. Sci Signal 289 (5480):768

71. Matsushika A, Makino S, Kojima M, Mizuno T (2000) Circadian waves of expression of the APRR1/TOC1 family of pseudo-response regulators in Arabidopsis thaliana: insight into the plant circadian clock. Plant Cell Physiol 41 (9):1002-1012

72. Imamura A, Hanaki N, Umeda H, Nakamura A, Suzuki T, Ueguchi C, Mizuno T (1998) Response regulators implicated in His-to-Asp phosphotransfer signaling in Arabidopsis. Proc Natl Acad Sci U S A 95 (5):2691-2696

73. Mizuno T (2004) Plant response regulators implicated in signal transduction and circadian rhythm. Curr Opin Plant Biol 7 (5):499-505

74. Robert LS, Robson F, Sharpe A, Lydiate D, Coupland G (1998) Conserved structure and function of the Arabidopsis flowering time gene CONSTANS in Brassica napus. Plant Mol Biol 37 (5):763-772

75. Nozue K, Covington MF, Duek PD, Lorrain S, Fankhauser C, Harmer SL, Maloof JN (2007) Rhythmic growth explained by coincidence between internal and external cues. Nature 448 (7151):358-361. doi:10.1038/nature05946

76. Niwa Y, Yamashino T, Mizuno T (2009) The circadian clock regulates the photoperiodic response of hypocotyl elongation through a coincidence mechanism in Arabidopsis thaliana. Plant Cell Physiol 50 (4):838-854

77. Lorrain S, Allen T, Duek PD, Whitelam GC, Fankhauser C (2008) Phytochrome-mediated inhibition of shade avoidance involves degradation of growth-promoting bHLH transcription factors. Plant J 53 (2):312-323

78. Carré IA, Kim JY (2002) MYB transcription factors in the Arabidopsis circadian clock. J Exp Bot 53 (374):1551-1557

79. Saikumar P, Murali R, Reddy EP (1990) Role of tryptophan repeats and flanking amino acids in Myb-DNA interactions. Proc Natl Acad Sci U S A 87 (21):8452-8456

80. Nakamichi N, Kiba T, Henriques R, Mizuno T, Chua N-H, Sakakibara H (2010) PSEUDO-RESPONSE REGULATORS 9, 7, and 5 are transcriptional repressors in the Arabidopsis circadian clock. The Plant Cell $22(3): 594-605$

81. Asakura Y, Hagino T, Ohta Y, Aoki K, Yonekura-Sakakibara K, Deji A, Yamaya T, Sugiyama T, Sakakibara H (2003) Molecular characterization of His-Asp phosphorelay signaling factors in maize leaves: implications of the signal divergence by cytokinin-inducible response regulators in the cytosol and the nuclei. Plant Mol Biol 52 (2):331-341

82. Carre I, Veflingstad S (2013) Emerging design principles in the Arabidopsis circadian clock. Semin Cell Dev Biol 24 (5): Academic Press, 2013.

83. Makino S, Kiba T, Imamura A, Hanaki N, Nakamura A, Suzuki T, Taniguchi M, Ueguchi C, Sugiyama T, Mizuno T (2000) Genes encoding pseudo-response regulators: insight into His-to-Asp phosphorelay and circadian rhythm in Arabidopsis thaliana. Plant Cell Physiol 41 (6):791-803

84. Gendron JM, Pruneda-Paz JL, Doherty CJ, Gross AM, Kang SE, Kay SA (2012) Arabidopsis circadian clock protein, TOC1, is a DNA-binding transcription factor. Proc Natl Acad Sci U S A 109 (8):3167-3172 
85. Dixon LE, Knox K, Kozma-Bognar L, Southern MM, Pokhilko A, Millar AJ (2011) Temporal Repression of Core Circadian Genes Is Mediated through EARLY FLOWERING 3 in Arabidopsis. Curr Biol 21 (2):120-125

86. Hazen SP, Schultz TF, Pruneda-Paz JL, Borevitz JO, Ecker JR, Kay SA (2005) LUX ARRHYTHMO encodes a Myb domain protein essential for circadian rhythms. Proc Natl Acad Sci U S A 102 (29):10387-10392

87. Li G, Siddiqui H, Teng Y, Lin R, Wan X-y, Li J, Lau O-S, Ouyang X, Dai M, Wan J (2011) Coordinated transcriptional regulation underlying the circadian clock in Arabidopsis. Nat Cell Biol 13 (5):616-622

88. Helfer A, Nusinow DA, Chow BY, Gehrke AR, Bulyk ML, Kay SA (2011) LUX ARRHYTHMO encodes a nighttime repressor of circadian gene expression in the Arabidopsis core clock. Curr Biol 21 (2):126-133

89. Liew LC, Hecht V, Sussmilch FC, Weller JL (2014) The pea photoperiod response gene STERILE NODES is an ortholog of LUX ARRHYTHMO. Plant Physiol 165 (2):648-657

90. Huang W, Pérez-García P, Pokhilko A, Millar A, Antoshechkin I, Riechmann J, Mas P (2012) Mapping the core of the Arabidopsis circadian clock defines the network structure of the oscillator. Sci Signal 336 (6077):75

91. Khan S, Rowe SC, Harmon FG (2010) Coordination of the maize transcriptome by a conserved circadian clock. BMC Plant Biol 10 (1):126

92. Turner A, Beales J, Faure S, Dunford R, Laurie D (2005) The pseudo-response regulator ppd-h1 provides adaptation to photoperiod in barley. Science 310 (5750):1031-1034

93. Beales J, Turner A, Griffiths S, Snape JW, Laurie DA (2007) A pseudo-response regulator is misexpressed in the photoperiod insensitive Ppd-D1a mutant of wheat (Triticum aestivum L.). Theor Appl Genet 115 (5):721-733

94. Shaw LM, Turner AS, Laurie DA (2012) The impact of photoperiod insensitive Ppd-1a mutations on the photoperiod pathway across the three genomes of hexaploid wheat (Triticum aestivum). The Plant Journal 71 (1):71-84

95. Chen A, Li C, Hu W, Lau MY, Lin H, Rockwell NC, Martin SS, Jernstedt JA, Lagarias JC, Dubcovsky J (2014) PHYTOCHROME C plays a major role in the acceleration of wheat flowering under long-day photoperiod. Proc Natl Acad Sci U S A 111 (28):10037-10044

96. Jung C, Mu“ller AE (2009) Flowering time control and applications in plant breeding. Trends Plant Sci 14:563-573

97. Xue W, Xing Y, Weng X, Zhao Y, Tang W, Wang L, Zhou H, Yu S, Xu C, Li X (2008) Natural variation in Ghd7 is an important regulator of heading date and yield potential in rice. Nat Genet 40 (6):761-767

98. Doi K, Izawa T, Fuse T, Yamanouchi U, Kubo T, Shimatani Z, Yano M, Yoshimura A (2004) Ehd1, a B-type response regulator in rice, confers short-day promotion of flowering and controls FT-like gene expression independently of $H d 1$. Genes Dev 18 (8):926-936

99. Takahashi Y, Teshima KM, Yokoi S, Innan H, Shimamoto K (2009) Variations in Hd1 proteins, Hd3a promoters, and Ehd1 expression levels contribute to diversity of flowering time in cultivated rice. Proc Natl Acad Sci U S A 106 (11):4555-4560. doi:10.1073/pnas.0812092106

100. Zhao J, Huang X, Ouyang X, Chen W, Du A, Zhu L, Wang S, Deng XW, Li S (2012) OsELF3-1, an ortholog of Arabidopsis EARLY FLOWERING 3, regulates rice circadian rhythm and photoperiodic flowering. PLOS ONE 7 (8):e43705. doi:10.1371/journal.pone.0043705

101. Hudson KA (2010) The circadian clock-controlled transcriptome of developing soybean seeds. The Plant Genome 3 (1):3-13. doi:10.3835/plantgenome2009.08.0025

102. Preuss SB, Meister R, Xu Q, Urwin CP, Tripodi FA, Screen SE, Anil VS, Zhu S, Morrell JA, Liu G (2012) Expression of the Arabidopsis thaliana BBX32 gene in soybean increases grain yield. PLoS ONE 7 (2):e30717

103. Hecht V, Knowles CL, Vander Schoor JK, Liew LC, Jones SE, Lambert MJM, Weller JL (2007) Pea LATE BLOOMER1 is a GIGANTEA ortholog with roles in photoperiodic flowering, deetiolation, and transcriptional regulation of circadian clock gene homologs. Plant Physiol 144 (2):648-661

104. Raju AS, Rao SP (2006) Explosive pollen release and pollination as a function of nectar-feeding activity of certain bees in the biodiesel plant, Pongamia pinnata (L.) Pierre (Fabaceae). Curr Sci (Bangalore) 90 (7):960-967

105. Pesti J (1976) Daily fluctuations in the sugar content of nectar and periodicity of secretion in the Compositae. Acta Agron Acad Sci Hung 25 (5):17 
106. Gimenes M, Benedito-Silva A, Marques M (1996) Circadian rhythms of pollen and nectar collection by bees on the flowers of Ludwigia elegans (Onagraceae). Biol Rhythm Res 27 (3):281-290

107. Radhika V, Kost C, Mithöfer A, Boland W (2010) Regulation of extrafloral nectar secretion by jasmonates in lima bean is light dependent. Proceedings of the National Academy of Sciences 107 (40):17228-17233

108. Farré EM (2012) The regulation of plant growth by the circadian clock. Plant Biol (Stuttg) 14 (3):401410. doi:10.1111/j.1438-8677.2011.00548.x

109. Devlin PF (2002) Signs of the time: environmental input to the circadian clock. J Exp Bot 53 (374):15351550 


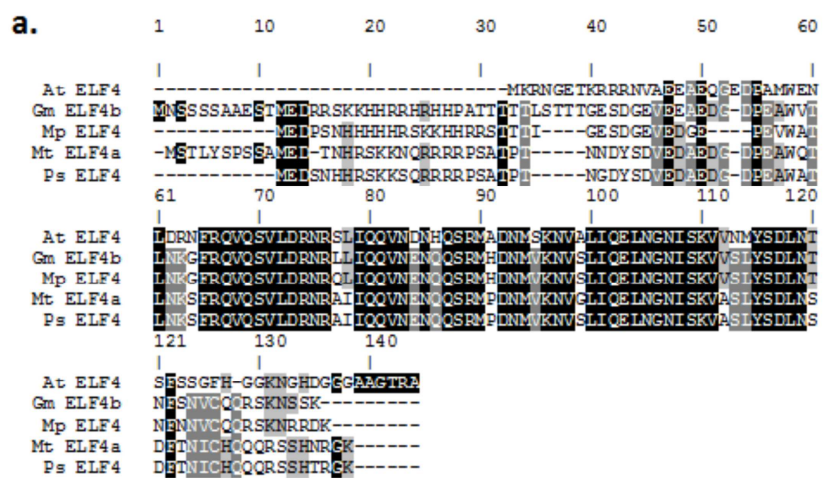

b.

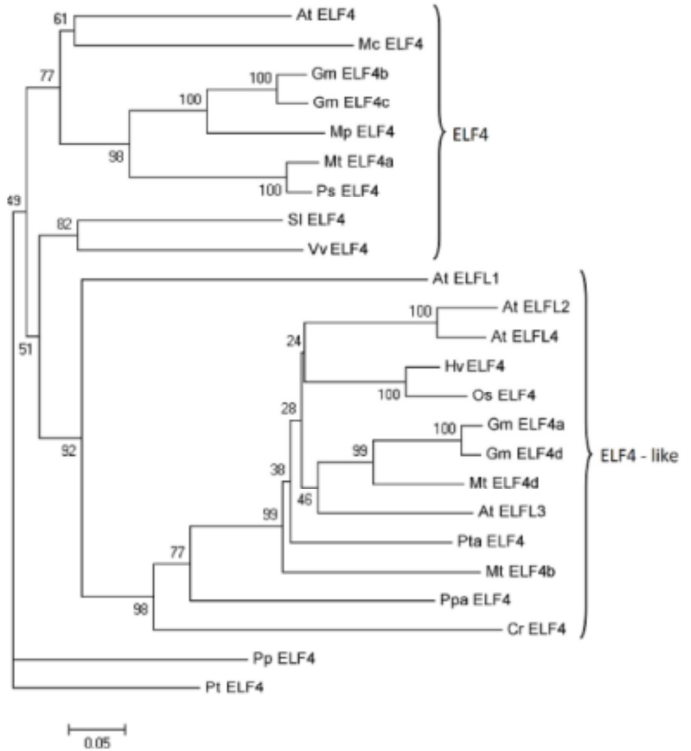

c.

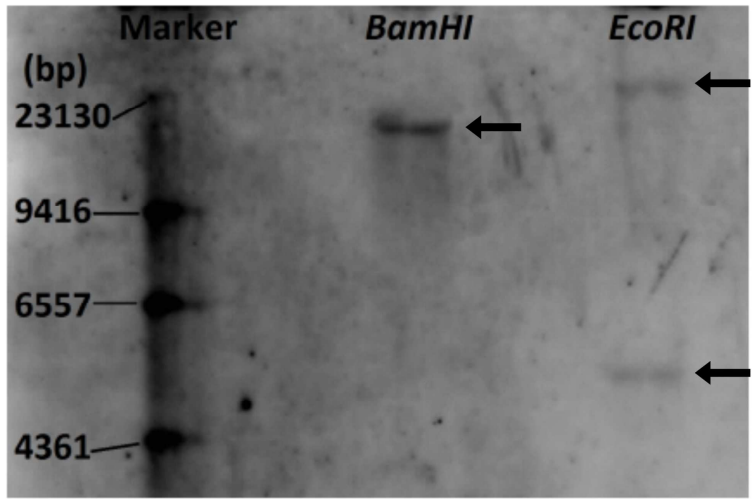

d.

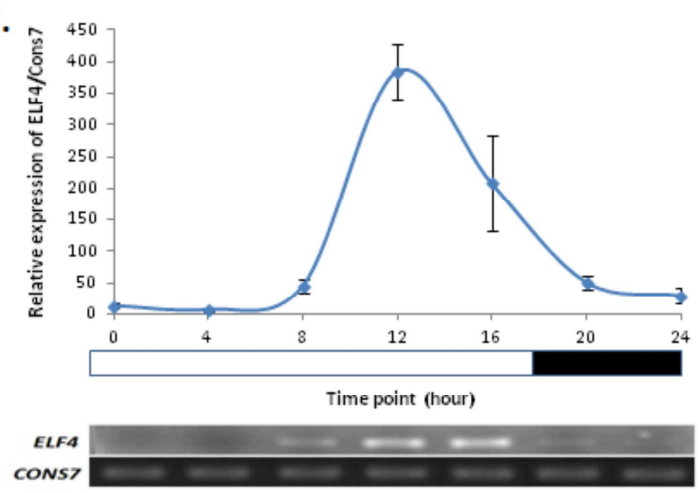



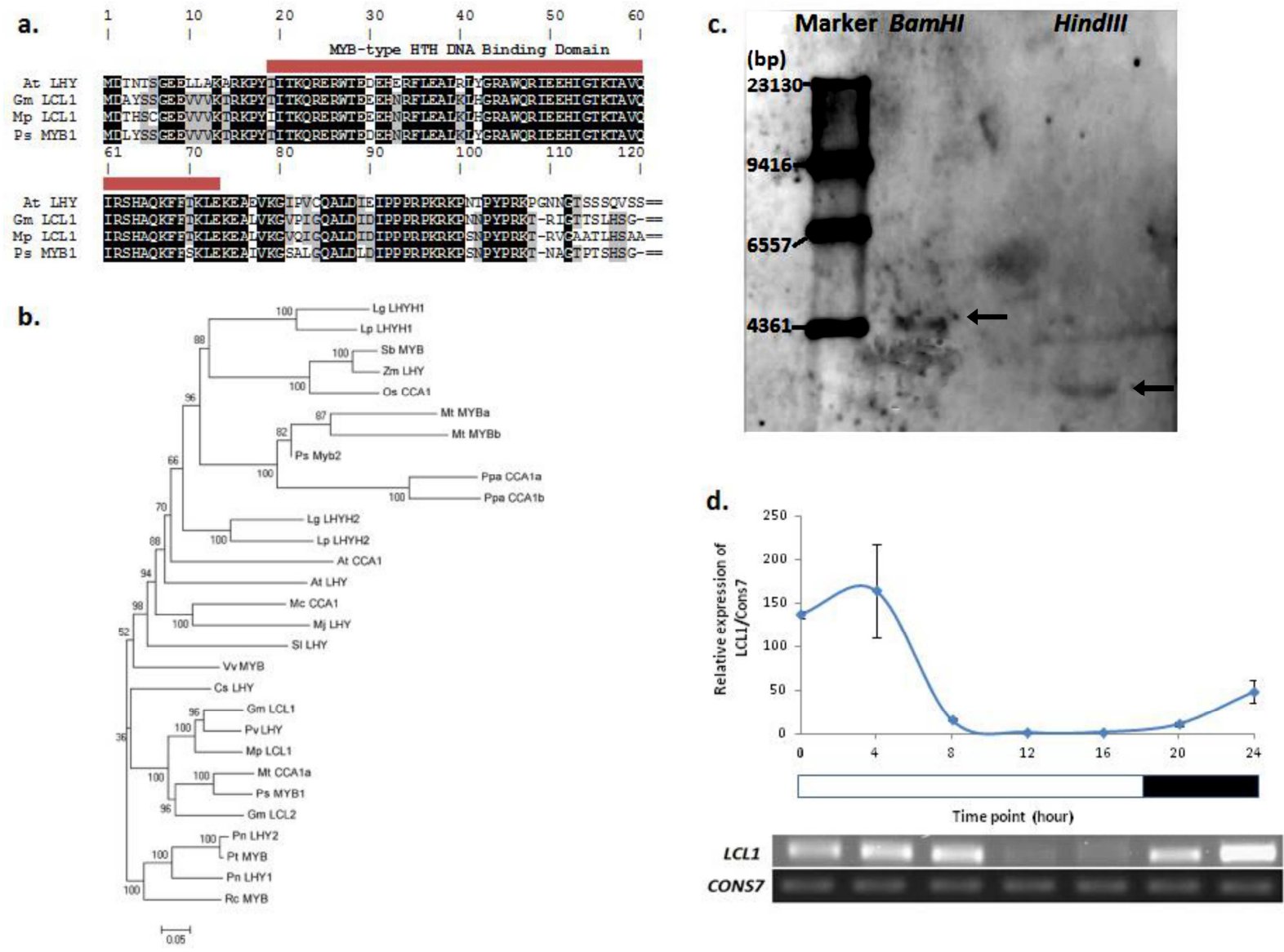

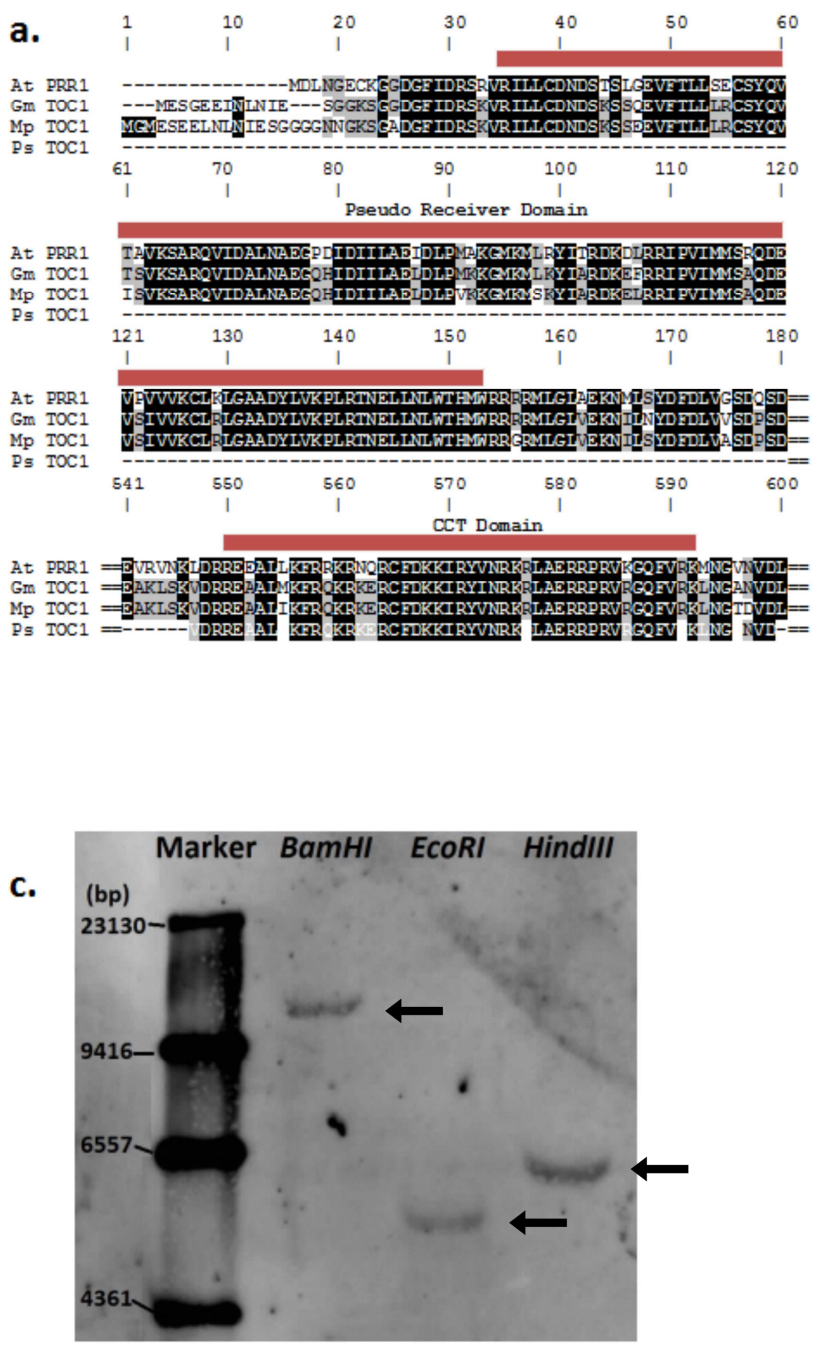
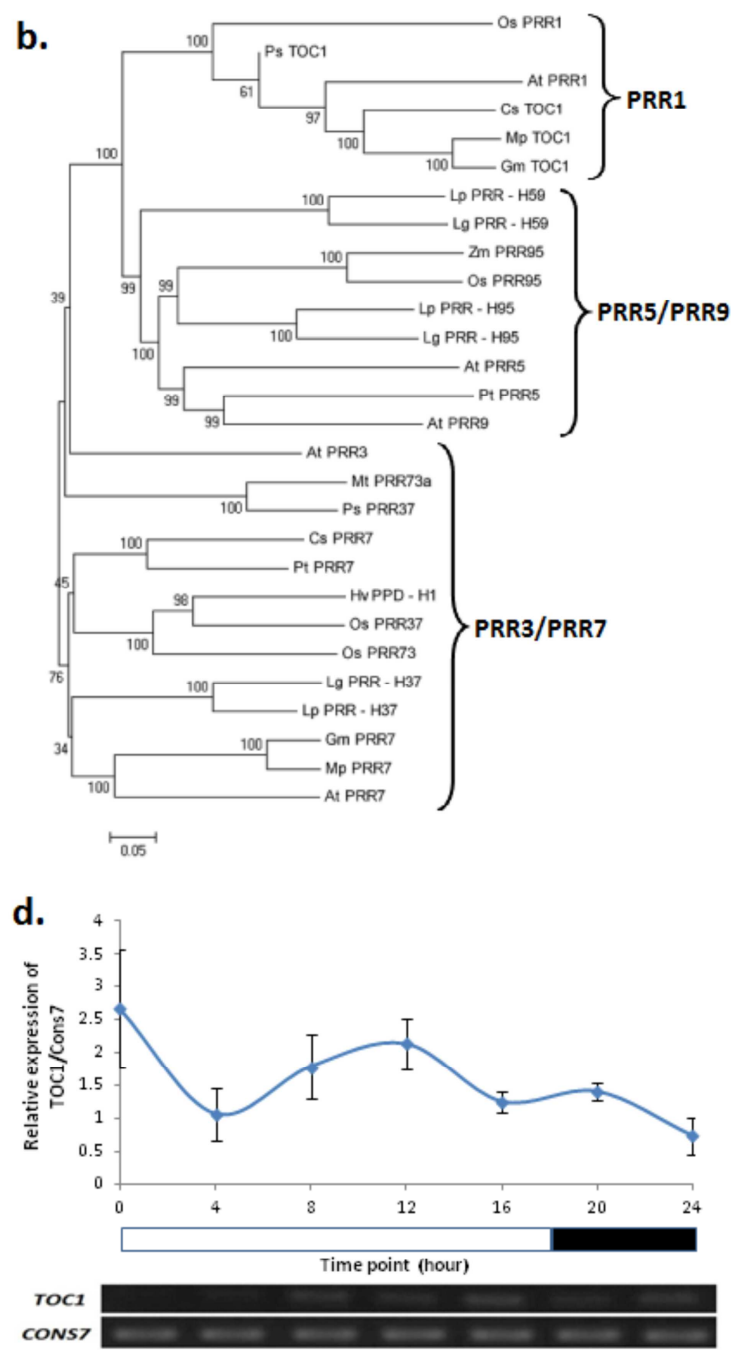

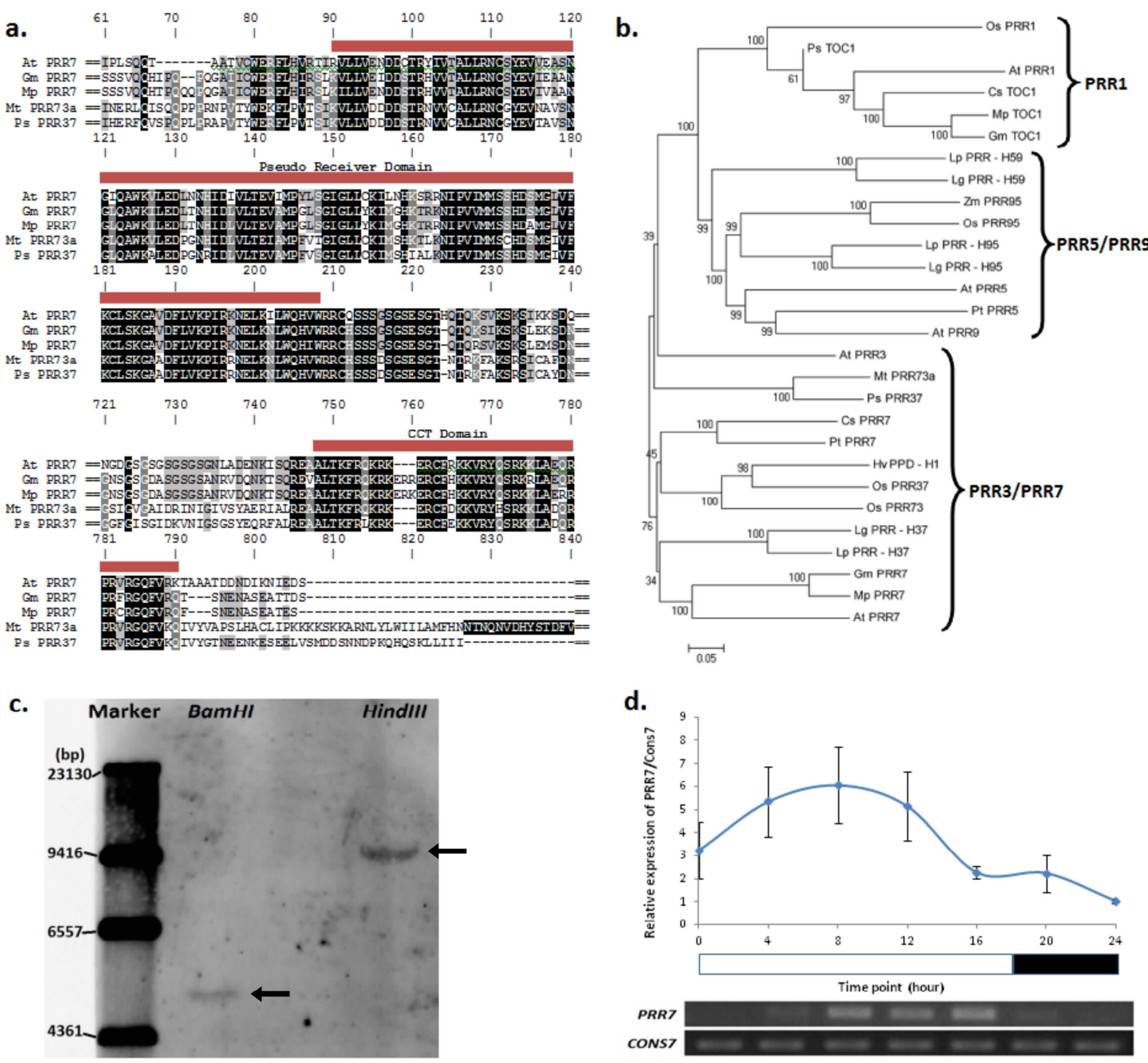


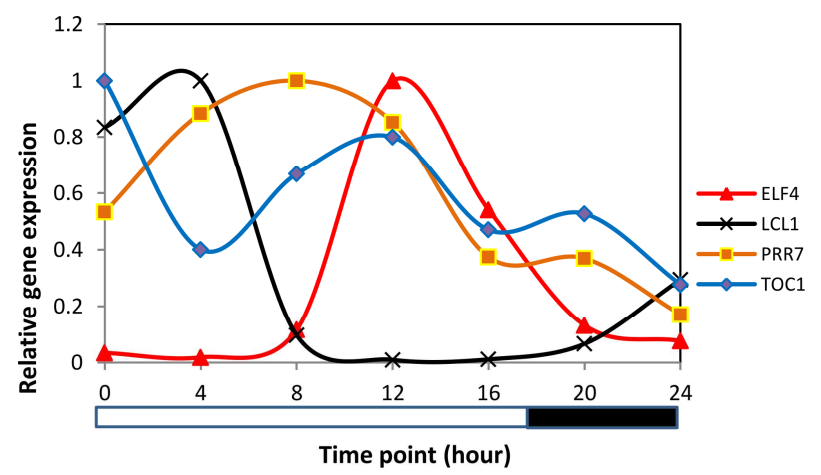




\section{University Library}

\section{- M M N E R VA A gateway to Melbourne's research publications}

Minerva Access is the Institutional Repository of The University of Melbourne

Author/s:

Winarto, HP;Liew, LC;Gresshoff, PM;Scott, PT;Singh, MB;Bhalla, PL

Title:

Isolation and Characterization of Circadian Clock Genes in the Biofuel Plant Pongamia (Millettia pinnata)

Date:

2015-06-01

\section{Citation:}

Winarto, H. P., Liew, L. C., Gresshoff, P. M., Scott, P. T., Singh, M. B. \& Bhalla, P. L. (2015). Isolation and Characterization of Circadian Clock Genes in the Biofuel Plant Pongamia (Millettia pinnata). BIOENERGY RESEARCH, 8 (2), pp.760-774. https://doi.org/10.1007/ s12155-014-9556-Z.

Persistent Link:

http://hdl.handle.net/11343/282949 